\title{
Flow cytometric analysis of bacteria- and virus-like particles in lake sediments
}

\author{
Solange Duhamel, Stéphan Jacquet* \\ UMR CARRTEL, Equipe de Microbiologie Aquatique, Station INRA d'Hydrobiologie Lacustre, 75 Avenue de Corzent, \\ 74203 Thonon-les-Bains cx, France
}

Received 17 March 2005; received in revised form 11 May 2005; accepted 23 May 2005

Available online 2 August 2005

\begin{abstract}
Flow cytometry (FCM) was successfully used to analyze freshwater bacteria and viruses in lake sediments after relatively simple sample treatment and optimization of dilution/fixation/staining procedures. Biological particles from Lakes Geneva and Bourget were first separated from the sediments by using both Sodium Pyrophosphate (0.01 M final concentration) and Polyoxyethylene-Sorbitan Monooleate (10\% final concentration) and sonicating for 3 min in a water bath. The best results (based on FCM signature and the highest virus and bacterial yields from the sediments) were obtained by formaldehyde fixation carried out within less than one hour ( $2 \%$ final concentration, vs. no fixation or using glutaraldehyde at different concentrations), SYBR-Green II staining $(\times 1 / 20,000$ stock solution concentration, vs. use of SYBR-Gold and SYBR-Green I dyes at different concentrations). There was a considerable loss of particles after only a few days of storage at either 4 or $-22{ }^{\circ} \mathrm{C}$. For FCM analysis, the samples were diluted in Tris-EDTA buffer $(\mathrm{pH} 8)$ and heated for 10 min at $75{ }^{\circ} \mathrm{C}$ after incubating for 5 min in the dark. The bacterial and viral counts paralleled those obtained using epifluorescence microscopy (EFM), but EFM always gave lower counts than FCM. Analysis of the distribution of the viruses in the water column and in the sediments of Lakes Bourget revealed a marked gradient, with larger quantities in the top layer of the sediment than in the water above it. These results are discussed, as well as the possible novel application of flow cytometry in the study of aquatic viral ecology. (C) 2005 Elsevier B.V. All rights reserved.
\end{abstract}

Keywords: Viruses; Bacteria; Lakes; Sediments; Flow cytometry; Epifluorescence microscopy

\section{Introduction}

Flow cytometry provides a method for high-speed multi-parametric data acquisition and analysis. During

\footnotetext{
* Corresponding author. Tel.: +33 4502678 12; fax: +33 45026 0760 .

E-mail address: jacquet@thonon.inra.fr (S. Jacquet).
}

the last two decades, it has been successfully used to analyze and count pelagic microbial communities of organisms such as protists, small algae, bacteria and viruses (Chisholm et al., 1988; Button and Robertson, 1989; Courties et al., 1994; Marie et al., 1999a,b; Lindström et al., 2002; Rose et al., 2004), to identify and quantify population DNA content and/or to investigate the cell cycle (Boucher et al., 1991; Marie et

0167-7012/\$ - see front matter (C) 2005 Elsevier B.V. All rights reserved. doi:10.1016/j.mimet.2005.05.008 
al., 1996, 1997; Gasol et al., 1999), to identify populations of interest using molecular probes (Simon et al., 1995; Wallner et al., 1996; Lange et al., 1996), to assess cellular physiology (Jochem, 2000; Lebaron et al., 2001), etc. Reviews have been published of the accuracy of this technique applied to the field of aquatic sciences and ecology in particular, and to the modification/optimization of the apparatus and procedures (Olson et al., 1991; Yentsch et al., 1983; Davey and Kell, 1996; Porter et al., 1996; Dubelaar et al., 1999; Veldhuis and Kraay, 2000; Vives-Rigo et al., 2000; Collier and Campbell, 2000; Gruden et al., 2004).

Since Marie et al. (1999a,b), viruses in the water column have been counted using benchtop flow cytometers on several occasions (Marie et al., 1999a,b; Brussaard et al., 2000; Chen et al., 2001; Jacquet et al., 2002a,b). Previously, viruses in aquatic environments were investigated using either transmission electron microscopy (TEM) or epifluorescence microscopy (EFM). Estimates of viral levels were first obtained using TEM after ultrafiltration or ultracentrifugation procedures (Bergh et al., 1989; Borsheim et al., 1990; Sime-Ngando et al., 1996). Since 1959, TEM has also been used to visualize phages, and characterize their morphology (Field, 1982). The use of EFM combined with the development of a variety of highly fluorescent nucleic acid specific dyes soon became the accepted method, because it involved a faster and less expensive technology. Nowadays, viruses (especially bacteriophages) are still usually counted by EFM using fluorochromes, such as SYBR Green I, SYBR Green II, SYBR Gold or YoPro I (Xenopoulos and Bird, 1997; Marie et al., 1999a,b; Shopov et al., 2000; Hewson et al., 2001a,b,c; Chen et al., 2001; Middelboe et al., 2003; Wen et al., 2004).

There have only been a few studies comparing the efficiency of the different techniques (such as EFM, FCM and TEM) for direct total counts of viruses in aquatic pelagic ecosystems. However, these comparisons make it possible to conclude that all these methods are fairly suitable for counting viruses (Hara et al., 1991; Hennes and Suttle, 1995; Weinbauer and Suttle, 1997; Marie et al., 1999a,b; Bettarel et al., 2000; Chen et al., 2001), even though it seems that FCM has been reported to be as efficient as EFM or between 1 and 2 times more efficient (Marie et al., 1999a,b; Brussaard et al., 2000; Chen et al., 2001; Dorigo et al., in revision), which in turn is reported to be up to seven times more efficient than TEM (Hara et al., 1991; Hennes and Suttle, 1995; Weinbauer and Suttle, 1997; Noble and Fuhrman, 1998; Bettarel et al., 2000). To the best of our knowledge, only Noble (2001) found TEM and EFM to have exactly the same efficiency levels for counting bacteriophages. The advantages and disadvantages of the three methods mentioned above, and a comparison of their efficiency can also be found in Weinbauer's excellent review on prokaryotic viruses (Weinbaueur, 2004).

Viruses are now considered to constitute an important component of aquatic microbial communities. They have been shown to be the most abundant biological compartment, and to play a crucial role in bacterial mortality, diversity and diversification in the pelagos (Wommack and Colwell, 2000; Weinbauer, 2004). Typically, viral infections are responsible for $20-50 \%$ of daily prokaryotic mortality, and they are a major source of dissolved organic matter. There has been little investigation of their importance in the sediment domain, where even basic information, such as their temporal dynamics and spatial distribution, is almost non-existent. However, sediments play a key role in the aquatic carbon cycle, and a high proportion of carbon degradation may be mediated by benthic processes (Glud and Middelboe, 2004). Since the work of Paul et al. (1993) and Maranger and Bird (1996), it has been known that high concentrations of viruses can occur in lake and marine surface sediments, typically reaching concentrations 10 to 1000 fold higher than those in the water column above, these densities being generally related to the trophic status of the ecosystem. In theory, aquatic sediments could provide an optimal environment (and hence constitute a reservoir) for virus development, since potential hosts (typically bacteria) are found in higher numbers than in the water column above, concentrations of organic matter are relatively high, and the distances between cells are very small (Wiggins and Alexander, 1985). Although, Danovaro and Serresi (2000) found large quantities of viruses and bacteria in a variety of sediments in the Eastern Mediterranean Sea, the low virus-to-bacterium ratios and their inverse relationship with trophic status suggest that the role played by viruses in controlling deep-sea benthic bacterial assemblages and biogeochemical cycles may 
be less relevant than in the pelagic systems. In another study, Danovaro et al. (2002) found that the lowest viral counts were obtained at stations where the largest cell sizes and the lowest bacterial growth and turnover rates were reported. These authors have suggested that the bacterial doubling time may play an important role in limiting virus development in sediments, and may influence the life strategies of benthic viruses. Recently, Middelboe and colleagues (Middelboe et al., 2003; Glud and Middelboe, 2004) clearly showed that the benthic viral community can be very dynamic, morphologically diverse and coupled with benthic bacterial activity. In freshwater ecosystems, high viral abundance but low virus-to-bacterium ratios have also been reported in lake sediments, suggesting that these particles are again only loosely related (Maranger and Bird, 1996; Lemke et al., 1997; Gessner et al. personal communication). At least, it seems that viral activity has only limited impact on benthic biogeochemical cycling (Middelboe, 2005). Clearly, only scant information about benthic viral ecology is available, and there are still no obvious conclusions about the importance and role of the viriobenthos.

To date, and to the best of our knowledge, viral abundance in aquatic sediments has always been determined using EFM or TEM. In this paper, we set out i) to propose an alternative way of counting viruses using flow cytometry combined with optimization of the extraction/fixation/dilution/staining procedure and ii) to report for the first time some typical concentrations of viruses and bacteria in the lake sediments of the two largest natural French lakes: Lakes Bourget and Geneva.

\section{Materials and methods}

\subsection{Study sites}

Lake Geneva $\left(46^{\circ} 27^{\prime} \mathrm{N}, 06^{\circ} 32^{\prime} \mathrm{W}, 372.05 \mathrm{~m}\right.$ altitude) is the largest natural western European lake, and is located between the eastern part of France and Switzerland. It is a mesotrophic lake. It is elongated in shape (72.3 and $13.8 \mathrm{~km}$ in length and width respectively) and west-east orientated, with an area of $580.1 \mathrm{~km}^{2}$, a total volume of $89 \times 10^{9} \mathrm{~m}^{3}$, maximum and average depths of 309.7 and $152.7 \mathrm{~m}$ respectively, and a water residence time of approxi- mately 11.4 years. It has a catchment area of about $7395 \mathrm{~km}^{2}$, with average altitude of $372.05 \mathrm{~m}$ above the sea.

Lake Bourget $\left(45^{\circ} 44^{\prime} \mathrm{N}, 05^{\circ} 51^{\prime} \mathrm{W}, 231 \mathrm{~m}\right.$ altitude) is the largest natural French lake, and is also located in the eastern part of France, on the edge of the Alps. It is a warm, meromictic lake. It is elongated in shape (18 and $3.5 \mathrm{~km}$ in length and width respectively) and north-south orientated, with an area of $42 \mathrm{~km}^{2}$, a total volume of $3.5 \times 10^{9} \mathrm{~m}^{3}$, maximum and average depths of 145 and $80 \mathrm{~m}$ respectively, and a water residence time of approximately 10 years. It has a catchment area of about $560 \mathrm{~km}^{2}$, with maximum and average altitudes of 1845 and $700 \mathrm{~m}$ respectively.

\subsection{Sampling strategy}

The sediment samples were collected using a Mortimer coring bit. For the different tests (see below), sediments were sampled in Lake Geneva, in front of the Station INRA d'Hydrobiologie Lacustre. The part of the study centered on microbial ecology was then carried out on samples collected during a limnological French program known as DYLACHEM (http://www. ipgp.jussieu.fr/rech/lge/dylachem/dylachem.html) on Lake Bourget. It is important to say here that it is assumed that the results of tests performed on Geneva lake sediments also apply to the Lake Bourget sediments since these sediments had a relatively similar porosity and grain size and because these two lakes have the same trophic status (not shown). In addition depths of sampling were the same for the two lakes.

\subsection{Tests of the protocol}

The protocol we propose (see Discussion) draws mainly on the work done by the Danovaro's team a few years ago (Danovaro et al., 2001). We carried out a battery of tests in an attempt to improve this proto$\mathrm{col}$, and to clear up certain problems. For all the tests, $0.5 \mathrm{ml}$ of sediment was taken and added to $3 \mathrm{ml}$ of $0.02-\mu \mathrm{m}$ filtered lake water, containing $0.2-\mu \mathrm{m}$ filtered fixative $(1 \%$ or $2 \%)$ and then kept at $4{ }^{\circ} \mathrm{C}$ for less than one hour. When working on the samples, as far as possible we kept them in a vat of ice (see Fig. 1).

The purpose of the first series of tests was to improve the extraction of the viruses and the bacteria from 


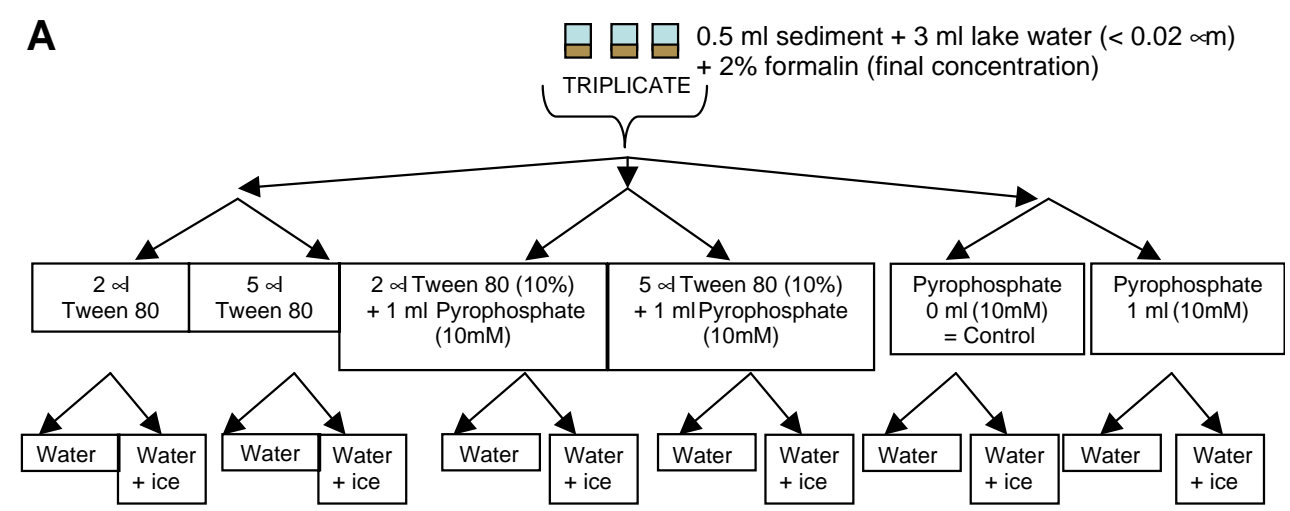

B

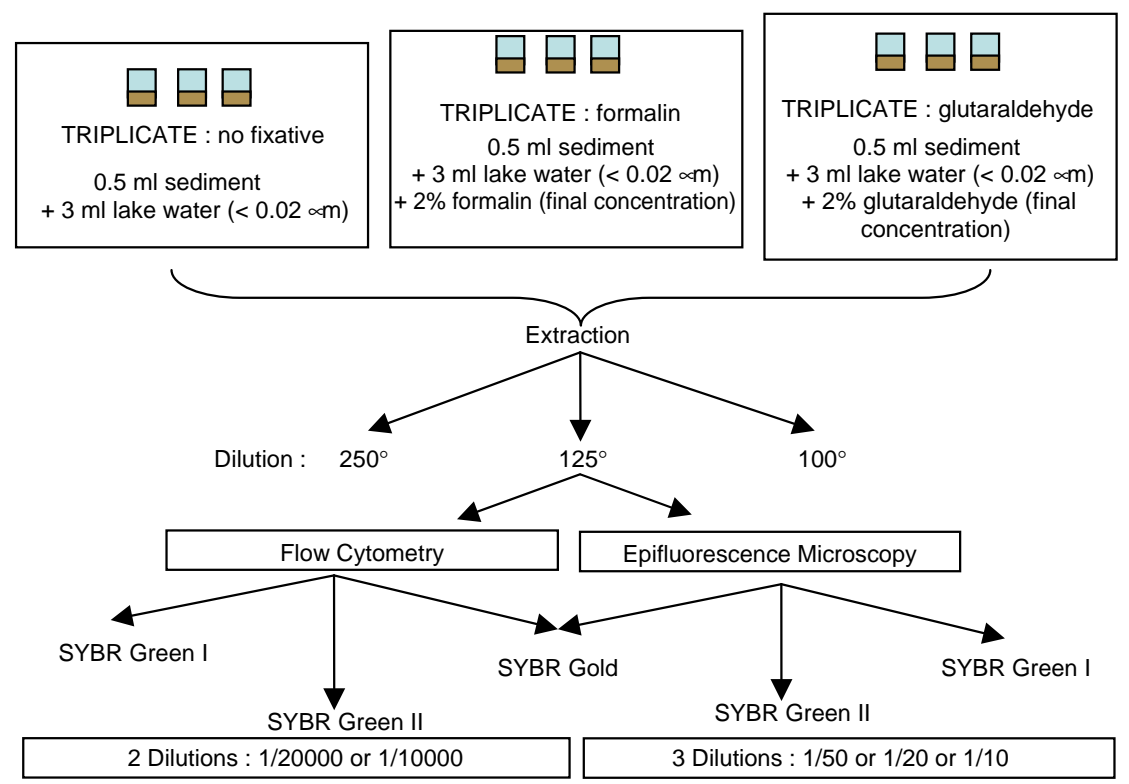

C

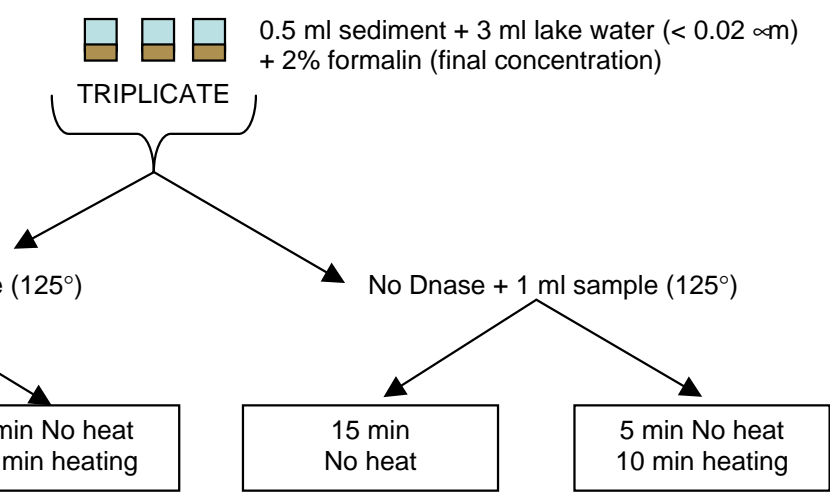

Fig. 1. Diagram of the protocols used for: A) the extraction and sonicating tests, B) the conservative, dilution and staining tests and C) the Dnase and heating tests. 
the sediment. To do this, we tested two products used in microbiology to disaggregate colonies of bacteria: Polyoxyethylene-Sorbitan Monooleate (Tween 80, Sigma) and Sodium Pyrophosphate (SP, Prolabo). The effectiveness of the two products was tested separately or together and in various combinations of concentrations $(5 \%$ and $10 \%$ for Tween 80 and 10 and $20 \mathrm{mM}$ for SP). To the best of our knowledge, it is the first time Tween 80 was used in such conditions (Fig. 1A). After adding these products for $15 \mathrm{~min}$, the protocol of Danovaro et al. (2001) recommended sonicating the samples for $3 \mathrm{~min}$, interrupting for $30 \mathrm{~s}$ every minute, during which time the samples are shaken manually. We used the same protocol provided by these authors and our apparatus was a Bransonic 220 (Sigma). To perform sonication, we tested the effectiveness of a water bath with or without adding ice to change the sonication properties (Fig. 1A). Following particle extraction, samples were shaken for one minute before centrifuging them at $800 \times g$ for $1 \mathrm{~min}$.

In order to eliminate any large sedimentation particles present, we filtered the supernatant of the sample through a $20-\mu \mathrm{m}$ filter. In the protocol of Danovaro et al. (2001), it was proposed that aliquots of the supernatant should be diluted 500 to 1000 fold. In the case of Lake Geneva, a preliminary test (not shown) had demonstrated that this range of dilutions was too high. We therefore tested the effect of lower dilutions $(250,125$ and 100) on the counts of bacteria and viruses in the sediment (Fig. 1B). Simultaneously, we tested the effect of different fixatives and/or concentrations of a given fixative, i.e., formalin $(1 \%$ or $2 \%)$, glutaraldehyde (1\% or $2 \%)$ and no fixative (Fig. 1B).

In order to eliminate uncertainties in virus counting due to extracellular DNA interference, we tested the effect of nuclease treatment on sediment samples by using $1 \%$ final concentration of DNAse for $1 \mathrm{~h}$ at ambient temperature (DNAse 1 RNAse free, Sigma, Fig. 1C).

The protocol of Danovaro et al. (2001) was drawn up for counting bacteria and viruses by means of epifluorescence microscopy. This protocol proposes staining $25 \mathrm{~mm}$ anodisc membranes with pore sizes of $0.02 \mu \mathrm{m}$ with $20 \mu \mathrm{l}$ of a 20 -fold dilution of SYBR Green I for $15 \mathrm{~min}$ in the dark. We tested various stains at various concentrations for both flow cytometry and epifluorescence microscopy (Fig. 1B). Indeed, we had recently demonstrated the importance of de- fining the best conditions in order to obtain reliable counts of microbial communities such as viruses and bacteria in alpine lakes (Dorigo et al., in revision). We tested three stains of the SYBR family: SYBR Green I, SYBR Green II and SYBR Gold. For the flow cytometry analyses, we compared 10,000 and 20,000 dilutions of the stock solution. For the epifluorescence microscopy analyses, we tested and compared $1 / 10$, $1 / 20$ and $1 / 50$ dilutions (Fig. 1B).

Finally, we carried out conservation tests after storing at $-22{ }^{\circ} \mathrm{C}$ for 5 or 30 days, and after fixing the sediment with either formalin $2 \%$ or glutaraldehyde $2 \%$ or without fixing them. We also tested the conservation of the sediment at $4{ }^{\circ} \mathrm{C}$ for $24 \mathrm{~h}$, after it had been extracted by the various methods shown in Fig. 1.

\subsection{Epifluorescence microscopy and flow cytometry analyses}

We used a FACSCalibur flow cytometer (Becton Dickinson) equipped with an air-cooled laser providing $15 \mathrm{~mW}$ at $488 \mathrm{~nm}$ with the standard filter set-up. Detailed protocols for bacterial and viral analyses have been described elsewhere (Marie et al., 1997, 1999a,b; Brussaard, 2004; Dorigo et al., in revision). Briefly, a $1-\mathrm{ml}$ sample was diluted with $0.02-\mu \mathrm{m}$ filtered TE (Tris-EDTA, $\mathrm{pH}=8$ ) buffer. Samples were stained with SYBR Green I, II or Gold (for example at a 1/20,000 final dilution of the stock solution supplied by manufacturer) and incubated for $5 \mathrm{~min}$ in the dark before being heated for $10 \mathrm{~min}$ to $75{ }^{\circ} \mathrm{C}$. We waited for $5 \mathrm{~min}$ after heating before carrying out the analysis. FCM listmode files were analyzed using CYTOWIN (Vaulot, 1989).

We used an epifluorescence microscope (Leitz Wetzlar, Dialux 20) for counting both bacteria and viruses. An anti-fading solution was prepared $(10 \mu \mathrm{l}$ of a solution of $100 \mathrm{mg}$ P-phenylenediamine $+1.5 \mathrm{ml} 0.2 \mu \mathrm{m}$ filtered MilliQ water was added to $495 \mu \mathrm{lBS}+495$ $\mu l$ glycerol) and filtered on $0.2 \mu \mathrm{m}$ before being kept at $4{ }^{\circ} \mathrm{C}$ just for the day of analysis. This solution was never used twice. The staining solution $(20 \mu \mathrm{l} \mathrm{SYBR}$ Green II, $1 / 20$ of the final dilution of the stock solution supplied by manufacturer, for example) was put in a Petri dish, where it formed a droplet, and was kept at 4 ${ }^{\circ} \mathrm{C}$ in the dark. $1 \mathrm{ml}$ of the fixed samples was filtered 
through a $25-\mathrm{mm}, 0.02-\mu \mathrm{m}$ ultra-fine pore size filter (Anodisc, Fisher Scientific), backed by a $25-\mathrm{mm} \mathrm{GF} / \mathrm{C}$ filter (Whatman), at low vacuum. This filter was then placed over the staining solution droplet for $20 \mathrm{~min}$ in the dark. The filter was finally mounted on a glass slide, and $30 \mu \mathrm{l}$ of the antifading solution was added following Noble (2001). Finally, a cover slip was placed over the filter. As suggested by Wen et al. (2004), the slides were prepared and counted on the same day. As for FCM, some tests in which the sample was heated were also done for EFM. To the best of our knowledge, this has never been done before and this is why we wanted to test the effectiveness of heating the sediment samples before EFM analysis. 4 tests were performed consisting in diluting the samples at $1 / 125$, with or without DNAse and by heating or not during 5 min just before filtration and staining.

EFM and FCM data with the best protocols defined above were finally compared from a mixture of two sediment samples of Lake Bourget and of Lake Geneva obtained by scuba-diving and using a manual core.

\subsection{Pelagic and benthic bacteria and viruses of Lake Bourget}

Pelagic and sediment microorganisms were investigated at two stations located in an eastern bay of Lake Bourget: Station I (35 m maximal depth) and R $(10 \mathrm{~m})$ on June 8 and 10, 2004, respectively. Sampling in the water column was carried out using a Niskin bottle at depths 2, 6, 10, 15, 20, $34 \mathrm{~m}$ for station I and 2, 6 and $9 \mathrm{~m}$ for station R. For the sediments obtained with the Mortimer coring bit, immediately after sampling, the sediment corers were vertically sectioned into five layers: 0 to 1,1 to 2,2 to 3,3 to 4,4 to $5 \mathrm{~cm}$ in depth after recuperation of the water column just above the sediment using a syringe with tubing.

\subsection{Statistical tests}

The bacterial and viral concentrations we found after the different treatments were compared and analyzed for significance using non-parametric tests. For any paired data, the Mann and Whitney $U$-test was used for a pair-wise comparison of the samples. Wilcoxon's $t$-test was used for any unpaired data.

\section{Results}

\subsection{Extraction of viruses and bacteria from the sediments}

The first series of tests dealt with the extraction of the bacterial and viral particles contained in the lake sediment. One of the first extraction steps reported in the literature consists of sonicating the sediment sample after adding sodium pyrophosphate. The different studies all agree that sonicating for 3 min efficiently dislodged viruses and bacteria from the sediment, but none made it clear whether adding ice to the water bath or not made for better efficiency. Our results clearly show that adding some ice to the sonication bath reduced the densities of free bacteria on average by $\sim 29 \%$ (Fig. 2A) and those of the viruses by $\sim 17 \%$ (Fig. 2B) (test $U, U_{\alpha / 2}=37, \alpha=0.5$ ). Adding Tween $80(10 \%)$ with or without the sodium pyrophosphate $(10 \mathrm{mM})$ increased the extraction efficiency, whereas this was not the case for DNase treatment after which significant lower numbers were found (not shown). The treatment which was the most effective was adding $5 \mu \mathrm{l}$ Tween $80(10 \%)+1 \mathrm{ml}$ sodium pyrophosphate $(10 \mathrm{mM})$ as plotted on Fig. 2, since we always observed significantly greater virus-like particle counts (increased by $\sim 25 \%$ to $40 \%$ ) than after the other treatments.

\subsection{Conservation of viruses and bacteria from the sediments}

When samples were kept for 30 days at a temperature of $-22{ }^{\circ} \mathrm{C}$, a statistically significant reduction in the number of viral particles $(76 \%$ on average) was recorded ( $U$-test, $U_{\alpha / 2}=17, \alpha=0.5$ ). Interestingly, keeping the samples at $4{ }^{\circ} \mathrm{C}$ for 5 days led to an average increase of $31 \%$ in viral particles (Fig. 3B), but to an average reduction in bacterial cells by approximately $51 \%$ (Fig. 3A). Keeping the samples did not lead to any statistically significant change in the bacterial counts obtained after between 5 and 30 days of storage (Fig. 3A). We also tested the effects of storing the samples for $24 \mathrm{~h}$ at $4{ }^{\circ} \mathrm{C}$, following the various extraction tests. Bacterial and viral densities were reduced by $9 \%$ to $40 \%$ and $0 \%$ to $54 \%$, respectively. The greatest reductions involved the samples treated with milliQ water in a bath containing water 

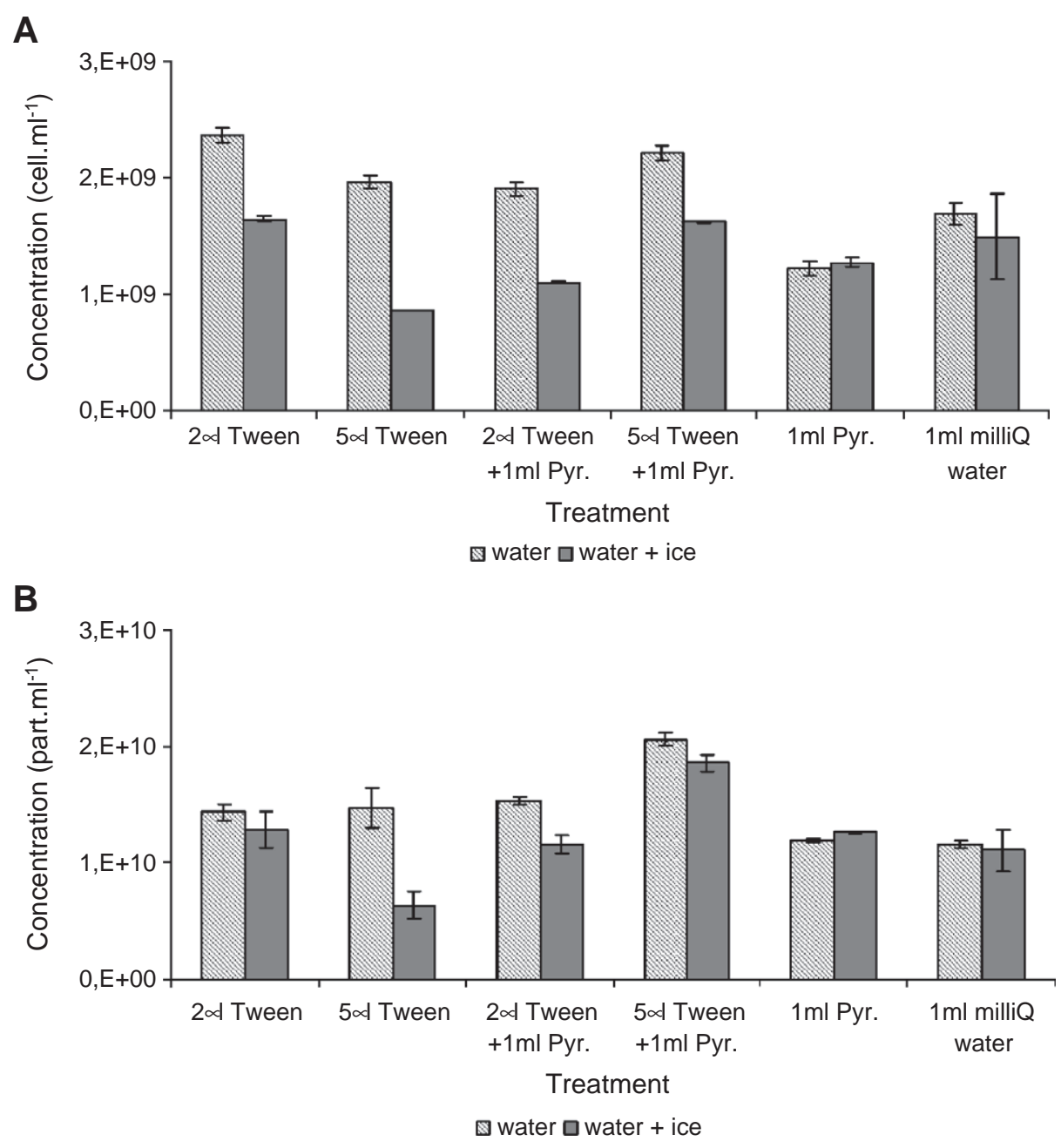

Fig. 2. Effects of Tween 80 and sodium pyrophosphate (pyr.) on the abundance of bacteria (A) and viruses (B) obtained by FCM.

plus ice. The less marked reductions occurred in the samples treated with $5 \mu$ of Tween 80 for viruses, or with $5 \mu \mathrm{l}$ of Tween 80 plus $1 \mathrm{ml}$ of sodium pyrophosphate for bacteria. We do not have any data for the temporal development of viral disappearance in these treatments, which would have been helpful to see for how long one can keep samples without significant loss.

\subsection{Fixation and dilution tests}

No fixation, formalin (1\% and $2 \%$ final concentration) and glutaraldehyde (1\% and $2 \%$ final concentration) were tested. No significant differences were recorded between the $1 \%$ and $2 \%$ treatment with either glutaraldehyde or formaldehyde (not shown). According to the Mann and Whitney $U$-test ( $U$-test, $U_{\alpha / 2}=17, \alpha=0.5$ ), there was no significant difference between viral counts for fixed or unfixed samples (Fig. 3B). In contrast, a significant difference was observed for the bacterial counts. Fixation with formalin made it possible to count on average 33\% more bacteria than after no treatment with preservative, and $77 \%$ more bacteria than after treatment with glutaraldehyde (Fig. 3A).

When using flow cytometry, bacterial and viral samples have to be diluted to avoid coincidence on the apparatus (Marie et al., 1999a,b). The dilution of 
A

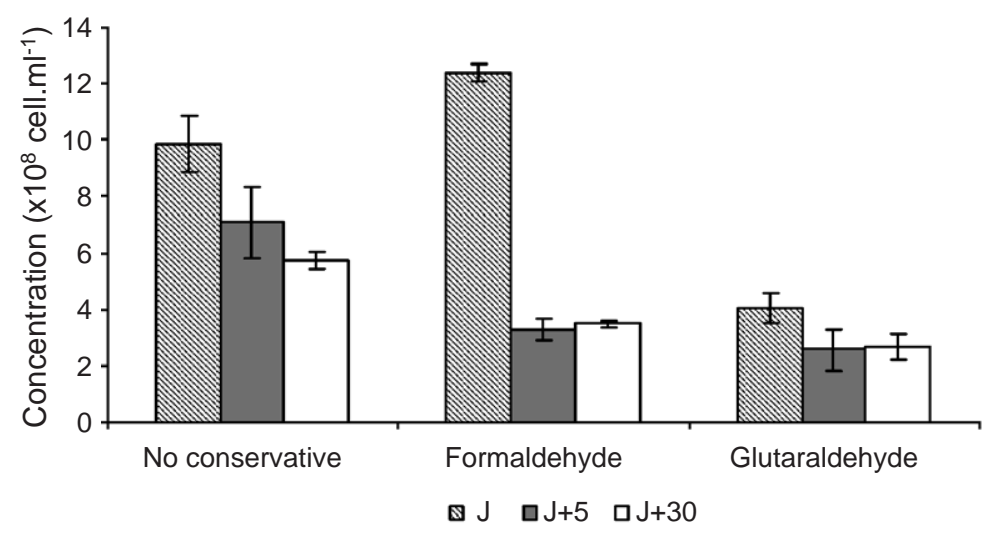

B

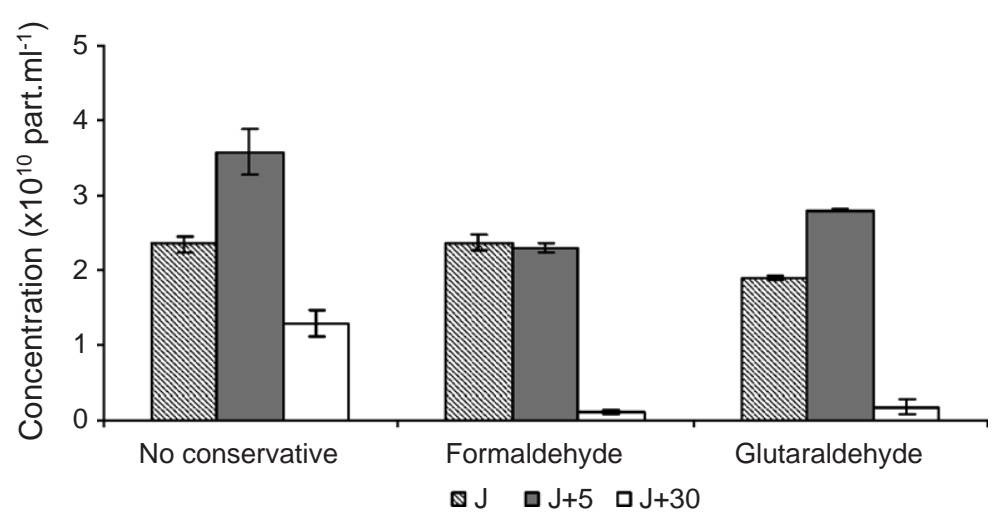

Fig. 3. Effects of the preservative and of conservation on the abundance of bacteria (A) and viruses (B) obtained by FCM.

the sample once the particles had been extracted clearly led to a modification of the apparent abundances of both bacteria and viruses (Fig. 4A, B). According to the Wilcoxon's $t$-test ( $t$-test, T $\alpha=8$, $\alpha=0.5$ ), we found $13 \%$ fewer bacteria in the $1 / 250$ dilution than in the $1 / 125$ dilution, and $17 \%$ fewer bacteria in the $1 / 250$ dilution than the $1 / 100$ dilution. For viruses, the corresponding percentages were $38 \%$ and $50 \%$.

\subsection{DNAse test}

The addition of DNAse at the time of the extraction involves an important reduction for both viral and bacterial counts ( $28 \%$ and $16 \%$ respectively) suggesting large amount of free DNA in the environment. Danovaro et al. (2001) found that extracellular-DNA removal increased virus counts since they found sig- nificantly higher virus densities in nuclease-treated samples.

\subsection{Staining tests}

We tested three different stains of the SYBR family, i.e., SYBR Green I, SYBR Green II and SYBR Gold. Two different dilutions were tested for FCM analysis: $1 / 10,000$ and $1 / 20,000$ (Fig. 4C, D) and four concentrations for EFM: $1 / 10,1 / 20,1 / 50$ and $1 / 1000$ (Fig. 4E). The best results with FCM (i.e., in terms of observations, signature and counts) were obtained when using SYBR Green II 1/20,000 for both bacteria and viruses. Also for EFM, SYBR Green II 1/20 was the stain with which the best results were obtained for bacteria (statistically and according to the observer). However, this was not true for viruses, for which the highest counts and good observations were obtained 
with SYBR Gold 1/1000. An extra step was also tested (not shown), consisting of heating the sample during the staining step for EFM. In contrast to FCM, heating led to a drastic reduction of the abundances $(\sim 50 \%)$ and thus is not recommended.

\subsection{FCM vs. EFM}

Using optimal protocols for each technique, a good correlation was found between the two methods for both bacteria $(r=0.84$, Fig. $5 \mathrm{~A})$ and viruses $(r=0.74$, Fig. $5 \mathrm{~B}$ ), suggesting that FCM is suitable to target and gives reliable counts for both bacteria and viruses in lake sediments. The comparison of the data obtained by the two methods showed that FCM always gave apparently greater bacterial and viral abundances than EFM by a factor varying between 1 and 2 (Fig. 5).
3.7. Distribution of viruses and bacteria in the sediment and overlying waters in Lake Bourget

When studying the sediments of Lake Bourget, we found that the abundance of benthic viruses was almost 200 times higher than in the overlying pelagic waters, and that the abundance of bacteria in the sediment was up to 2200 times higher than that in the overlying water. In Lake Bourget, we observed clear differences in the concentrations of viruses (Fig. 6B) and bacteria (Fig. $6 \mathrm{~A})$ at the two stations. Bacterial concentrations were higher at station $\mathrm{R}$ than at station $\mathrm{I}$, whereas viral concentrations were higher at station I. The peak bacterial concentration was found to occur deeper down (between 2 and $3 \mathrm{~cm}$ ) than that for the viruses (between 0 and $1 \mathrm{~cm}$ ). One-cm above the sediment, the counts of both bacteria and viruses were found to be relatively

A

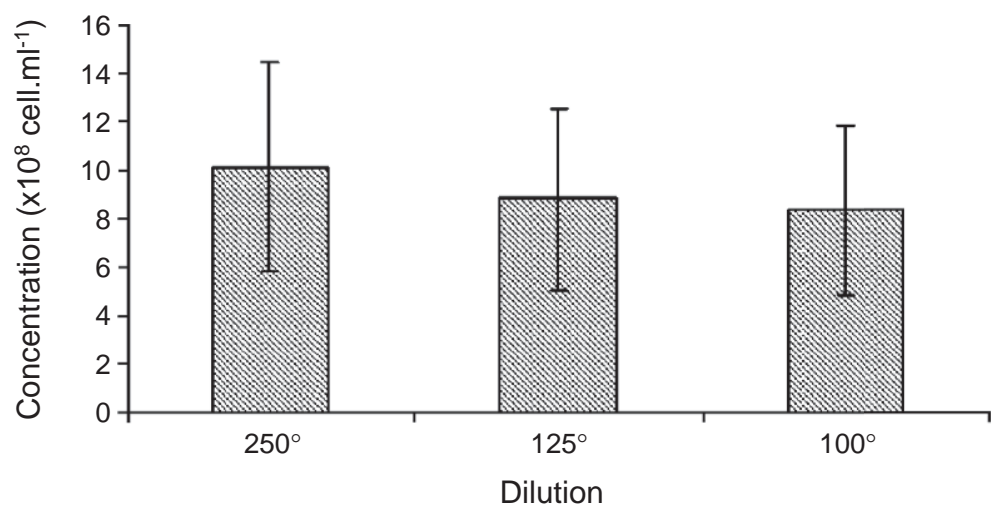

B

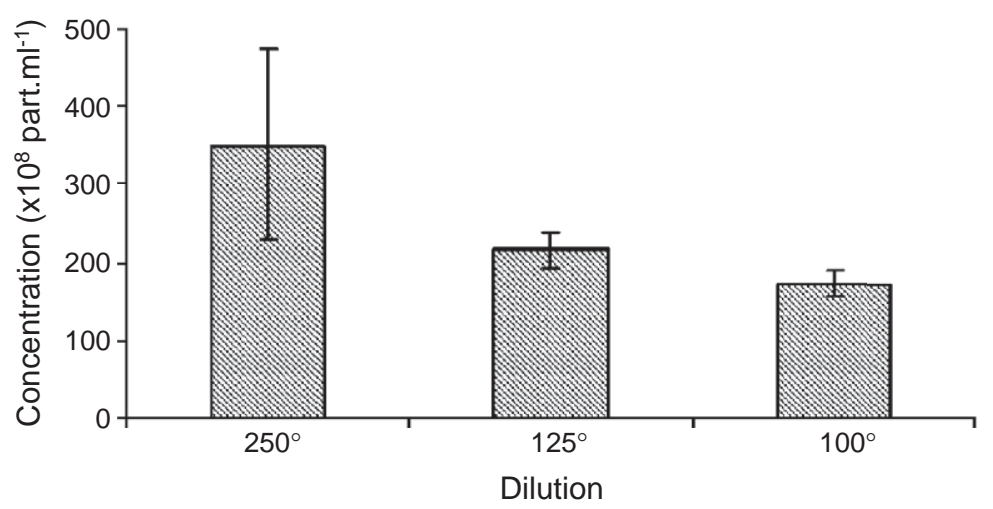

Fig. 4. Effects of sample dilution (A, B) and dyes concentration (C, D, E) on bacterial and viral abundances obtained using both FCM and EFM. 

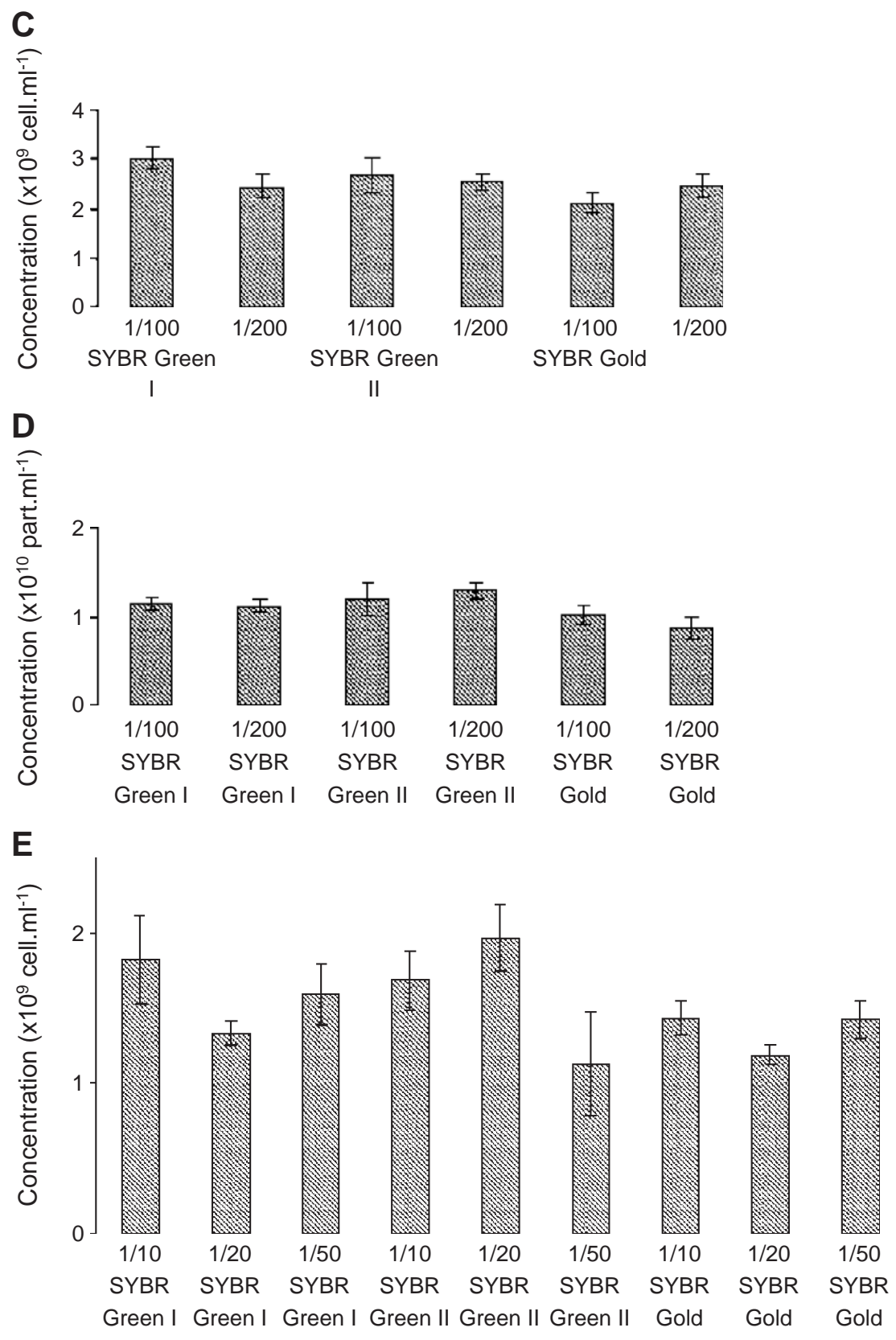

Fig. 4 (continued).

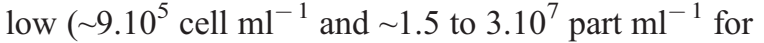
bacteria and viruses, respectively) compared to those in the first centimeter of the sediment (point I: $7.10^{8}$ cell

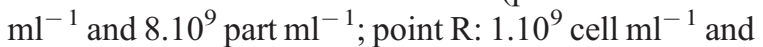

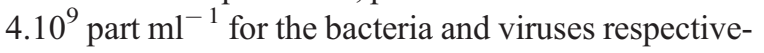

ly). VBR (the ratio between the viruses and bacteria) was also very different at the two stations (Fig. 6C). The mean ratio was 11.1 at station I for the $0-5 \mathrm{~cm}$ sediment, versus only 3.5 at station R. The VBR also varied significantly, and in a similar range, deeper in the 

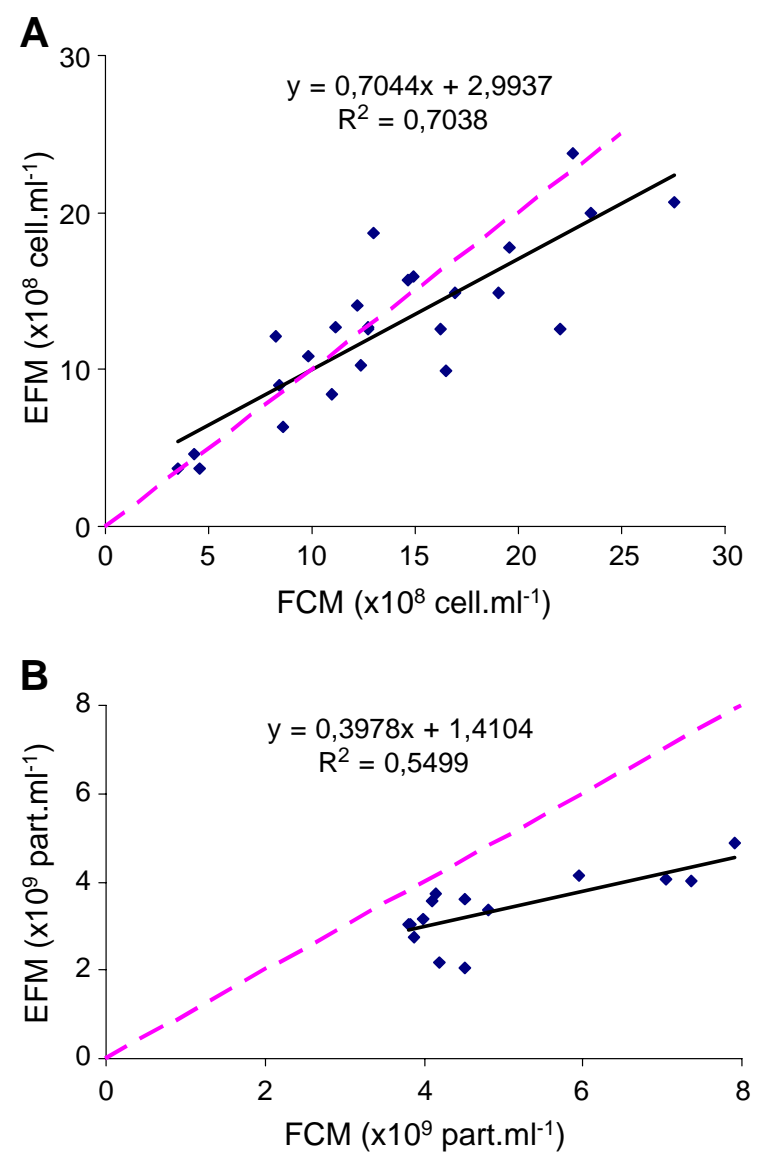

Fig. 5. Comparison of bacterial (A) and viral (B) abundances counted using EFM and FCM after optimization of the protocol.

sediment core (VBR values between 6 and 18 for station I and between 2 and 6 for station R). In the water column, the average VBR was higher: 13.3 and 19.4 fold for I and R respectively. Locally in the water column, VBR could reach values as high as 76 . Clearly VBR was always and significantly higher in the water column compared to the sediments.

\section{Discussion}

It is only a few years since Marie et al. (1999a,b) reported the successful use of a benchtop flow cytometer with a low-power argon-ion laser to detect and count viruses in seawater. We can now propose another application for this device, i.e., the detection and counting of viruses in aquatic (lake) sediments. There are many advantages of being able to use flow cytometry rather than epifluorescence microscopy or transmission electron microscopy. The most important advantage is probably the rapidity of the analysis, which makes it possible to use it for both routine and more exploratory analyses of microbial properties. When using FCM with the recent fluorescent nucleic acid dyes, the problem of the exposure time is not a problem, since it only takes a few milliseconds versus the several seconds or even minutes required to count the particles under the microscope. It is well known that the fluorescence of stains declines considerably and rapidly as a result of exposure to light. This means that it is likely that fewer cells or particles will be found when using EFM than FCM. With FCM, we also know that all particles present in a sample are counted whereas it is not the case with EFM for which only a part of the filter on the slide is observed. All these reasons have led us to develop a method of counting viruses and bacteria in the sediment using flow cytometry. With this goal in mind, we have optimized the protocol for EFM analysis developed by Danovaro et al. (2001), and demonstrated the efficiency of FCM analysis. The best protocol we found dealing with our devices and choices is given in Fig. 7.

The analysis of viruses and bacteria from sediment samples presents a major problem: the extraction process. The efficiency of different treatments has been discussed by several authors (e.g. Danovaro et al., 2001; Middelboe et al., 2003). Our findings suggest some additional ways of achieving a better method for extracting viruses and bacteria from the sediment in aquatic ecosystems. Typically, we used Tween 80 in addition to pyrophosphate solution, and demonstrated that adding both products gave better results than either separately. Tween 80 is a non-ionic detergent routinely used to produce selective protein extraction and to isolate nuclei from mammalian cell lines. Øvreås et al. (2003) reported using Tween 80 to separate viruses attached to bacteria or particles in water column samples. This is what gave us the idea of using it in this study to separate the bacteria and viruses attached to the sediment. Middelboe et al. (2003) have demonstrated that adding sodium pyrophosphate significantly increased the dislodgement of viruses from the sediment. Our results demonstrate the possible advantage of mixing these two products. 


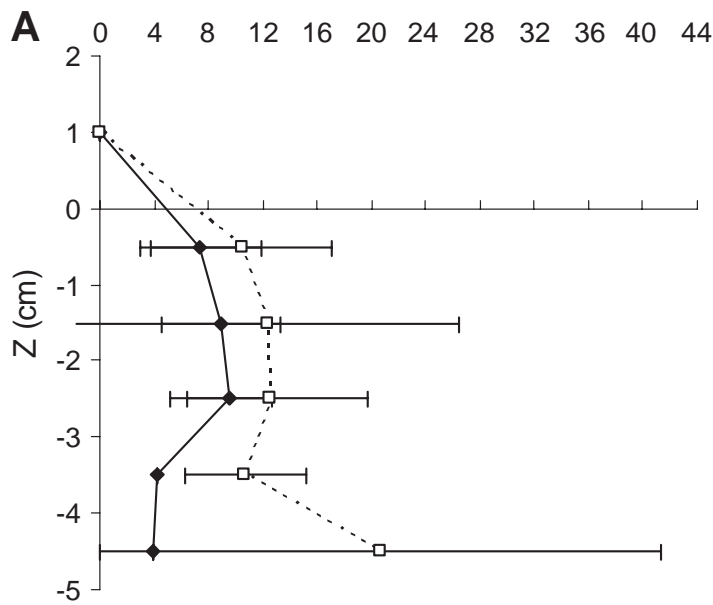

Bacterial concentration $\left(\times 10^{8}\right.$ bacteria $\left.\mathrm{ml}^{-1}\right)$
B

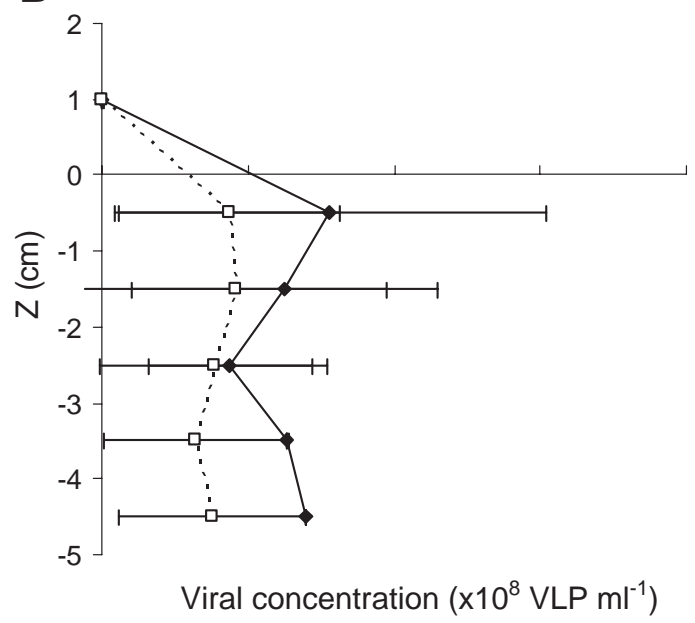

$\longrightarrow$ Point I _...... Point R

60

80

100
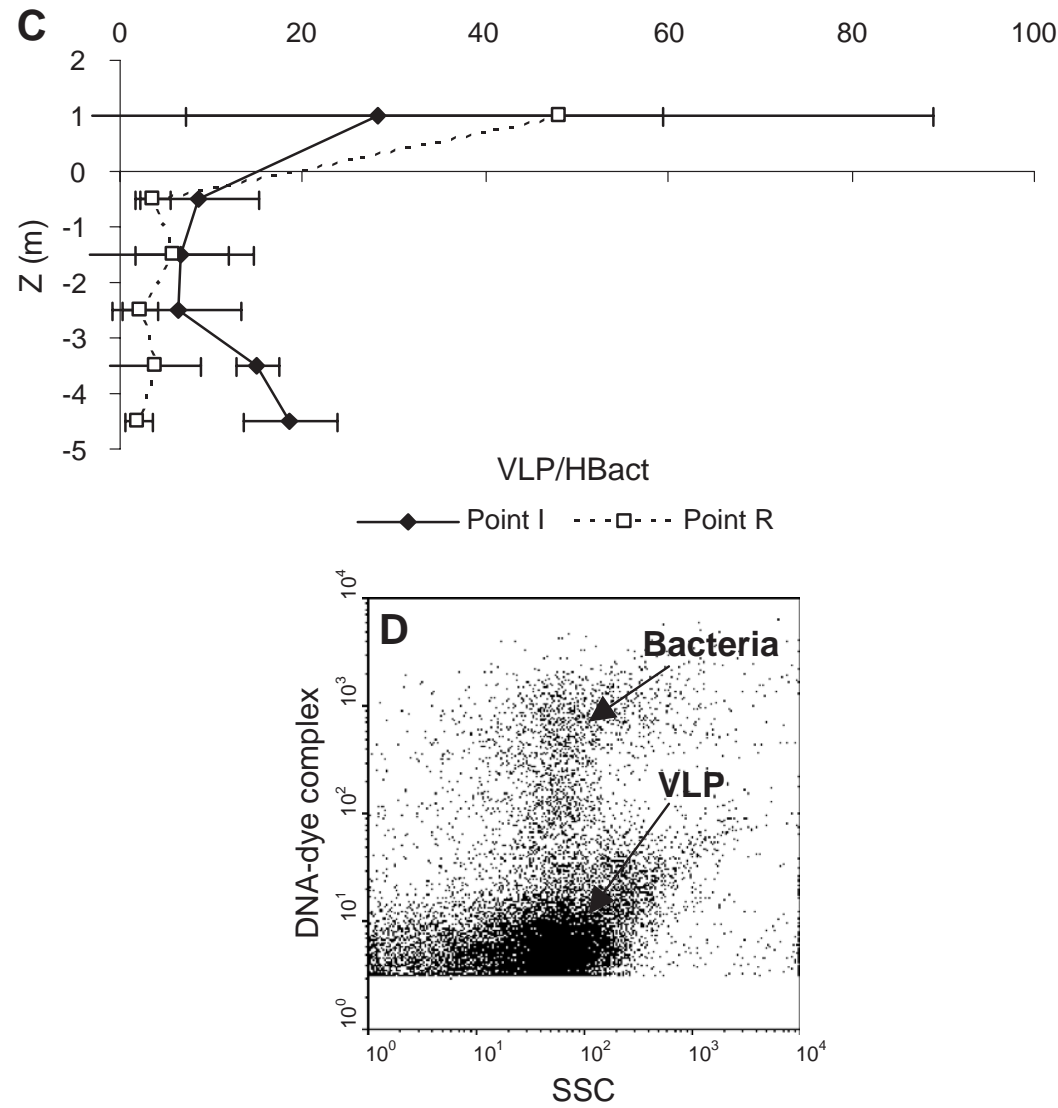

Fig. 6. Bacterial (A) and viral (B) abundances counted by FCM and variations of the VBR (C) in the sediment of Lake Bourget. A typical flow cytogram is represented (D). 


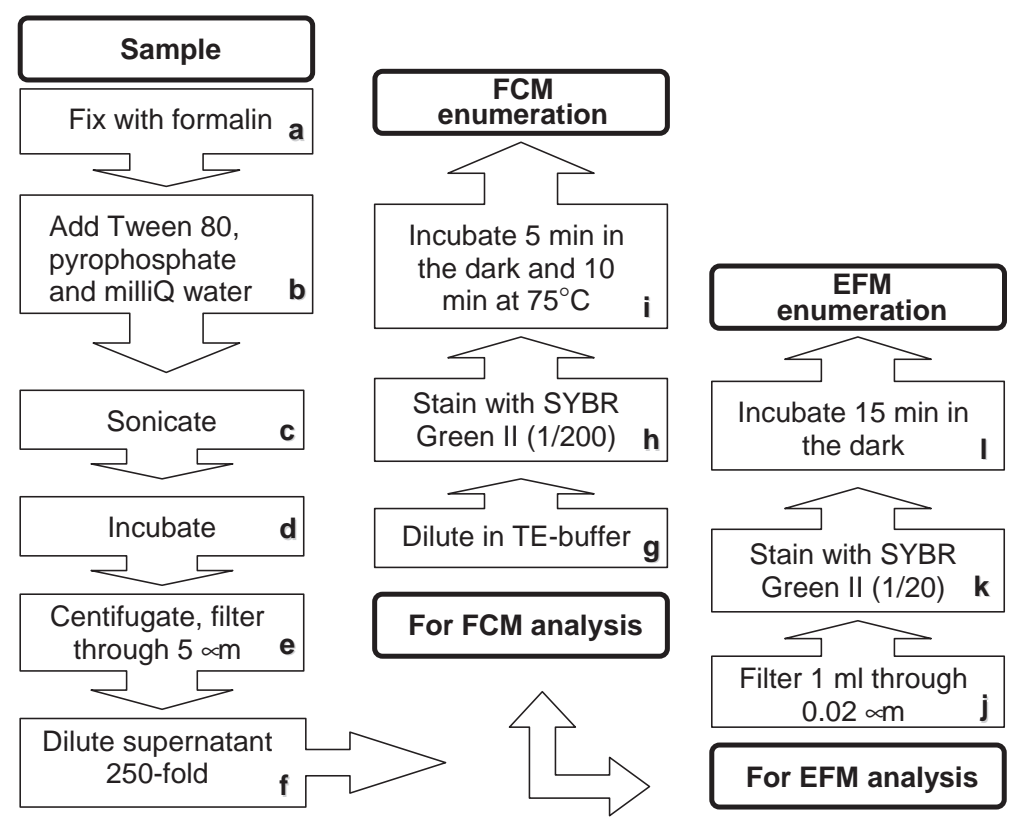

Fig. 7. Diagram of the improved protocol suggested on the basis of our findings. The sample is extracted and analyzed using FCM or EFM. a) $2 \%$ final concentration; b) $5 \mu \mathrm{l}$ Tween $80(10 \%)+1 \mathrm{ml}$ sodium pyrophosphate solution $(10 \mathrm{mM})+4 \mathrm{ml}$ MilliQ water; c) Sonicate 3 times for 1 $\mathrm{min}$ in a water bath. Shake manually after every minute; d) $15 \mathrm{~min}$ in an ice bath, then shake manually (1 min); e) Centrifuge $1 \mathrm{~min}(800 \times g)$, filtrate supernatant on a $5 \mu \mathrm{m}$ membrane; f) Dilute with MilliQ water; g) $490 \mu \mathrm{l} \mathrm{TE}$ (pre-filtered across $0.02 \mu \mathrm{m})+5-\mu 1 \mathrm{sample} ; \mathrm{h})+5 \mu \mathrm{l} \mathrm{SYBR}$ Green II (1/200) (final concentration $(1 / 20,000)$ ); i) Wait 5 min before doing the FCM count; j) Whatman Filter Anodisc 25 ; k) $10 \mu 1$; 1$) 4{ }^{\circ} \mathrm{C}$.

Nowadays, virus counting using both EFM and FCM is based on the use of highly fluorescent nucleic acid stains. SYBR Green I is one of the stains most commonly used to count pelagic marine viruses and bacteria by flow cytometry and epifluorescence microscopy (Marie et al., 1999a,b; Noble and Fuhrman, 1998). Sediment bacteria have been stained in solution with acridine orange or $4^{\prime}$,6-diamidino-2-phenylindole (DAPI), but high background fluorescence or non-specific staining often occurs. Weinbauer and Suttle (1997) advised using SYBR Green II, because it produces bright staining of soil and sediment bacteria. Similar conclusions were drawn by Lebaron et al. (1998), who tested SYBR Green II for water samples and flow cytometry. Recent studies involving viruses in aquatic sediments have used SYBR Green I (Danovaro et al., 2001; Hewson et al., 2003, etc). Our results show that SYBR Green II seems to be the most accurate for counting bacteria and virus from our lake sediment, for both EFM and FCM analysis. Indeed, the number of cells stained with SYBR Green II in EFM was closer to the number stained in FCM than with the other stains. Moreover, the background fluorescence observed in EFM was lower than with the other stains. This finding agrees with the study of Lebaron et al. (1998), who compared a panel of different blue-excited dyes for both freshwater and marine ecosystems. However, we make no attempt to claim that our findings can be extrapolated to all freshwater ecosystems, particularly since we did not reach the same conclusion for the pelagic viruses and bacteria of Lake Bourget and Geneva, for which the use of SYBR Green I or Gold could give better results (Dorigo et al., in revision)! It is likely that differences will be found between laboratories (because of the use of different instruments or buffer in relation to the different ecosystem types involved and the reaction of the dye to this material), so we suggest that there cannot be a single protocol ideal for all purposes. However, we believe that only minor adjustments will have to be carried out by anyone testing and using our protocol (Fig. 7).

Diluting the sample is a critical step when using FCM to analyze bacteria or viruses (Marie et al., 
1999a,b). This is an essential step in order to avoid coincidence on the machine, but it involves the risk that some information may be lost. At first sight, the findings of our tests investigating sample dilutions are surprising. The more the sample was diluted, the higher the counts per $\mathrm{ml}$ of bacteria and viruses we obtained. We do not have clear explanation for that. Testing the proper dilution and separation of living particles from the sediment seem critical, and this should be investigated further.

The decline of both viral and bacterial concentrations at 4 and $-22{ }^{\circ} \mathrm{C}$ within a few days could be due to clumping or to degradation of the viruses and bacteria by nucleases, as it has been reported for bacterial samples in seawater (Gundersen et al., 1996). Such a considerable loss highlighted the importance of analyzing the particles without delay.

It has been proposed on several occasions that sediments could constitute a potentially important reservoir of infectious bacteriophages from the water column (Weinbauer, 2004), cyanophages (Suttle, 2000) or algal viruses (Lawrence et al., 2002; Nagasaki et al., 2004). However, no processes involving the recruitment of viruses into sediments or their release from sediments have yet been clearly demonstrated. Previous studies have shown that viruses can be adsorbed onto sinking particles, and thus carried down to the sea-floor (Proctor and Fuhrman, 1990; Hewson et al., 2001a,b,c), so that sediments receiving a high influx of particles might also receive large inputs of viruses from the water column. The number of viruses in sediments might be dependent upon complex interactions with both abiotic factors (pressure, physical disturbance, redox conditions, and light effects) and biotic factors (high abundance of bacterial hosts, high bacterial metabolic rate, virus supply from above). Water mixing is likely to play a key role by producing the resuspension of the virus through the water column.

The occurrence of phages in aquatic sediments has been documented, but data about their total abundance are still rare. In freshwater sediments, viral abundance ranges from 2 to $71 \times 10^{8}$ particles $\mathrm{ml}^{-1}$ (Middelboe, 2005). Our data are consistent with these numbers. The abundance of benthic viruses has been shown to exceed that of water column viruses by 10 to 1000 fold (Paul et al., 1993; Maranger and Bird, 1996; Steward et al., 1996; Drake et al., 1998; Danovaro and Serresi, 2000). It has been suggested that the quantity of viruses present may reflect the trophic status of the ecosystem. For example, studies of the abundance of marine viruses in oligotrophic sediments have found between 100 and 1000 times more viruses than in the overlying water (Paul et al., 1993; Danovaro and Serresi, 2000; Hewson et al., 2001a,b,c), whereas in eutrophic areas, this difference is about 10 to 100 (Drake et al., 1998). In the sediment of Lake Bourget, we found that benthic viruses were at least 100 times more abundant than water column viruses. Lake Bourget is mesotrophic, so we can consider that our findings match those of studies of marine viruses. It is important to point out that there may be a high degree of horizontal variability (Middelboe et al., 2003). This was the case between point $\mathrm{R}$ and I in lake Bourget only separated by a few hundreds of meters.

The greater ratios of viruses to bacteria (VBRs) observed in sediments may be the result of greater nutrient availability in sediments (Hewson et al., 2001a,b,c). Elevated benthic VBRs may also result from higher bacterial activity associated with the greater substrate availability in sediments (Hewson et al., 2001a,b,c) or from the significant importation of viruses attached to sedimenting particles (Danovaro and Serresi, 2000). In Lake Bourget we found that the VBR was higher at I than R, suggesting a closer relationship between bacteria and viruses at this location. As we did not have the relevant nutrient data or hydrobiological circulation data, and also because these two stations were relatively close to each other, in the same bay, we cannot conclude that this is the case. Middelboe et al. (2003) have shown that viral abundance in sediments at depths of about $0.5 \mathrm{~m}$ in Danish waters was significantly correlated with both bacterial abundance and activity, suggesting that the distribution and abundance of viruses were closely coupled to the activity of the bacterial community, and that viruses are produced by bacteria within the sediment. Unlike Middelboe et al. (2003), we did not find any correlation between bacterial and virus abundance in the sediment of Lake Bourget. Given the low VBR ratio we found and corresponding to what has been reported worldwide (Middelboe, 2005), we could only suggest that there were probably weak relationships between bacteria and viruses in June in Lake Bourget but it is obvious that it is hard 
to conclude anything about bacteria-virus relationships from abundances at single sampling. However, this assumption was supported by TEM analyses of infected bacteria in the same sample, which always revealed less than $1 \%$ of visibly infected cells in the different strata of the first $0-5 \mathrm{~cm}$ of sediment (SimeNgando, personal communication).

\section{Acknowledgements}

SD was supported by an INRA contract. This study was funded by the DYLACHEM project. The flow cytometer has been funded by both INRA and University contracts. We are grateful to Monika Ghosh for improving the English. Mathias Middelboe is acknowledged for useful advice.

\section{References}

Bergh, O., Borsheim, K.Y., Bratbak, G., Heldal, M., 1989. High abundances of viruses found in aquatic environments. Nature 340, 467-468.

Bettarel, Y., Sime-Ngando, T., Amblard, C., Laveran, H., 2000. A comparison of methods for counting viruses in aquatic systems. Appl. Environ. Microbiol. 66, 2283-2289.

Borsheim, K.Y., Bratbak, G., Heldal, M., 1990. Enumeration and biomass estimation of planktonic bacteria and viruses by transmission electron microscopy. Appl. Environ. Microbiol. 56, $352-356$.

Boucher, N., Vaulot, D., Partensky, F., 1991. Flow cytometric determination of phytoplankton DNA in cultures and oceanic populations. Mar. Ecol., Prog. Ser. 71, 75-84.

Brussaard, C.P.D., 2004. Optimization of procedures for counting viruses by flow cytometry. Appl. Environ. Microbiol. 70, 1506-1513.

Brussaard, C.P.D., Marie, D., Bratbak, G., 2000. Flow cytometric detection of viruses. J. Virol. Methods 85, 175-182.

Button, D.K., Robertson, B.R., 1989. Kinetics of bacterial processes in natural aquatic systems bases on biomass as determined by high-resolution flow cytometry. Cytometry 10, 558-563.

Chen, F., Lu, J.-R., Binder, B.J., Liu, Y.-C., Hodson, R.E., 2001. Application of digital image analysis and flow cytometry to enumerate marine viruses stained with SYBR Gold. Appl. Environ. Microbiol. 67, 539-545.

Chisholm, S.W., Olson, R.J., Zettler, E.R., Goericke, R., Waterbury, J.B., 1988. A novel free living prochlorophyte abundant in the oceanic euphotic zone. Nature 334, 340-343.

Collier, J.L., Campbell, L., 2000. Flow cytometry in molecular aquatic ecology. Hydrobiol. 401, 33-53.

Courties, C., Vaquer, A., Trousselier, M., Chrétiennot-Dinet, M.-J., Neveux, J., Machado, C., Claustre, H., 1994. Smallest eukaryotic organism. Nature 370, 255.
Danovaro, R., Serresi, M., 2000. Viral density and virus-to-bacterium ratio in deep-sea sediments of the eastern Mediterranean. Appl. Environ. Microb. 66, 1857-1861.

Danovaro, R., Dellanno, A., Trucco, A., Serresi, M., Vanucci, S., 2001. Determination of virus abundance in marine sediments. Appl. Environ. Microbiol. 67, 1384-1387.

Danovaro, R., Manini, E., Dell'Anno, A., 2002. Higher abundance of bacteria than of viruses in deep Mediterranean sediments. Appl. Environ. Microbiol. 68, 1468-1472.

Davey, H.M., Kell, D.B., 1996. Flow cytometry and cell sorting of heterogeneous microbial populations: the importance of singlecell analysis. Microbiol. Rev. 60, 641-696.

Dorigo, U., Personnic, S., Jacquet, S. Necessary tests for accurate counting of freshwater microbial communities using either flow cytometry or epifluorescence microscopy. Syst. Appl. Microbiol. (in revision).

Drake, L.A., Choi, K.-H., Edward Haskell, A.G., Dobbs, F.C., 1998. Vertical profiles of virus-like particles and bacteria in the water column and sediments of Chesapeake Bay, USA. Aquat. Microb. Ecol. 16, 17-25.

Dubelaar, G.B.J., Gerritzen, P.L., Beeker, A.E.R., Jonker, R.R., Tangen, K., 1999. Design and first results of CytoBuoy: a wireless flow cytometer for in situ analysis of marine and fresh waters. Cytometry 37, 247-254.

Field, A.M., 1982. Diagnostic virology using electron microscopy. Adv. Viral. Res. 27, 1-69.

Gasol, J.M., Zweifel, U.L., Peters, F., Furhman, J.A., Hagstrom, A., 1999. Significance of size and nucleic acid content heterogeneity as measured by flow cytometry in natural planktonic bacteria. Appl. Environ. Microb. 65, $4475-4483$.

Glud, R.N., Middelboe, M., 2004. Virus and bacteria dynamics of a coastal sediment: implication for benthic carbon cycling. Limnol. Oceanogr. 49, 2073-2081.

Gruden, C., Skerlos, S., Adriaens, P., 2004. Flow cytometry for microbial sensing in environmental sustainability applications: current status and future prospects. FEMS Microbiol. Ecol. 49, $37-49$.

Gundersen, K., Bratbak, G., Heldal, M., 1996. Factors influencing the loss of bacteria in preserved seawater samples. Mar. Ecol., Prog. Ser. 137, 305-310.

Hara, S., Terauchi, K., Koike, I., 1991. Abundance of viruses in marine waters: assessment by epifluorescence and transmission electron microscopy. Appl. Environ. Microbiol. 57, 2731-2734.

Hennes, K.P., Suttle, C.A., 1995. Direct counts of viruses in natural waters and laboratory cultures by epifluorescence microscopy. Limnol. Oceanogr. 40, 1050-1055.

Hewson, I., O’Neil, J.M., Dennison, W.C., 2001a. Virus-like particles associated with Lyngbya majuscula (Cyanophyta; Oscillatoria) bloom decline in Moreton Bay, Australia. Aquat. Microb. Ecol. 25, 207-213.

Hewson, I., O’Neil, J.M., Heil, C.A., Bratbak, G., Demison, W.C., 2001b. Effects of concentrated viral communities on photosynthesis and community composition of co-occurring benthic microalgae and phytoplankton. Aquat. Microb. Ecol. $25,1-10$. 
Hewson, I., O’Neil, J.M., Furhman, J.A., Dennison, W.C., 2001c. Virus-like particle distribution and abundance in sediments and overlying waters along eutrophication gradients in two subtropical estuaries. Limnol. Oceanogr. 47, 1734-1746.

Hewson, I., Vargo, G.A., Fuhrman, J.A., 2003. Bacterial diversity in shallow oligotrophic marine benthos and overlying waters: effects of virus infection, containment, and nutrient enrichment. Microb. Ecol. 46, 322-336.

Jacquet, S., Havskum, H., Thingstad, F.T., Vaulot, D., 2002a. Effect of inorganic and organic nutrient addition on a coastal microbial community (Isefjord, Denmark). Mar. Ecol., Progr. Ser. 228, 3-14.

Jacquet, S., Heldal, M., Iglesias-Rodriguez, D., Larsen, A., Wilson, W., Bratbak, G., 2002b. Flow cytometric analysis of an Emiliana huxleyi bloom terminated by viral infection. Aquat. Microb. Ecol. 27, 111-124.

Jochem, F.J., 2000. Probing the physiological state of phytoplankton at the single cell level. Scienta Mar. 64, 183-195.

Lange, M., Guillou, L., Vaulot, D., Simon, N., Amann, R.I., Ludwig, W., Medlin, L.K., 1996. Identification of the class Prymnesiophyceae and the genus Phaeocystis with ribosomal RNAtargeted nucleic acid probes detected by flow cytometry. J. Phycol. 32, 858-868.

Lawrence, J.E., Chan, A.M., Suttle, C.A., 2002. Viruses causing lysis of the toxic bloom forming alga Heterosigma akashiwo (Raphidophyceae) are widespread in the coastal sediments of British Columbia, Canada. Limnol. Oceanogr. 47, 545-550.

Lebaron, P., Parthuisot, N., Catala, P., 1998. Comparison of blue nucleic acid dyes for flow cytometric enumeration of bacteria in aquatic systems. Appl. Environ. Microbiol. 64 (5), $1725-1730$.

Lebaron, P., Servais, P., Agogue, H., Courties, C., Joux, F., 2001. Does the high nucleic acid content of individual bacterial cells allow us to discriminate between active cells and inactive cells in aquatic systems? Appl. Environ. Microbiol. 67, 1775-1782.

Lemke, M., Wickstrom, C., Leff, L., 1997. Preliminary study on the distribution of viruses and bacteria in lotic environments. Arch. Hydrobiol. 141, 67-74.

Lindström, E.S., Weisse, T., Stadler, P., 2002. Enumeration of small ciliates in culture by flow cytometry and nucleic acid staining. J. Microbiol. Methods 49, 173-182.

Maranger, R., Bird, D.F., 1996. High concentrations of viruses in the sediments of Lac Gilbert, Quénec. Microb. Ecol. 31, $141-151$.

Marie, D., Vaulot, D., Partensky, F., 1996. Application of the novel nucleic-acid strains YOYO-1, YO-PRO-1 and PicoGreen for flow cytometric analyses of marine procaryotes. Appl. Environ. Microbiol. 62, 1649-1655.

Marie, D., Partensky, F., Jacquet, S., Vaulot, D., 1997. Enumeration and cell cycle analysis of natural populations of marine picoplankton by flow cytometry using the nucleic acid dye SYBRGreen I. Appl. Environ. Microbiol. 63, 186-193.

Marie, D., Brussaard, C., Partensky, F., Vaulot, D., 1999a. Flow cytometric analysis of phytoplankton, bacteria and viruses. Current Protocols in Cytometry. John Wiley \& Sons, Inc., pp. 11.11.1-11.11.15.
Marie, D., Bruussard, C., Bratbak, G., Vaulot, D., 1999b. Enumeration of marine viruses in culture and natural samples by flow cytometry. Appl. Environ. Microbiol. 65, 45-52.

Middelboe, M., 2005. Virus dynamics in marine sediments: implications for benthic carbon cycling. Conference at the 1st European Workshop on Aquatic Phage Ecology, Thonon, France.

Middelboe, M., Glud, R.N., Finster, K., 2003. Distribution of viruses and bacteria in relation to diagenic activity in an estuarine sediment. Limnol. Oceanogr. 48, 1447-1456.

Nagasaki, K., Tomaru, Y., Nakanishi, K., Hata, N., Katanozaka, N., Yamaguchi, M., 2004. Dynamics of Heterocapsa circularisquama (Dinophyceae) and its viruses in Ago Bay, Japan. Aquat. Microb. Ecol. 34, 219-226.

Noble, R.T., 2001. Enumeration of viruses. In: Paul, J.H. (Ed.), Methods in Microbiology, Marine Microbiology, vol. 30. Academic Press, pp. 43-51.

Noble, R., Furhman, J.A., 1998. Use of SYBR Green I for rapid epifluorescence counts of marine viruses and bacteria. Aquat. Microb. Ecol. 14, 113-118.

Olson, R.J., Zettler, E.R., Chisholm, S.W., Dusenberry, J.A., 1991. Advances in oceanography through flow cytometry. NATO ASI. Ser., Ser. G 27, 351-399.

Øvreås, L., Bourne, D., Sandaa, R.A., Casamayor, E.O., Benlloch, S., Goddard, V., Smerdon, G., Heldal, M., Thingstad, T.F., 2003. Response of bacterial and viral communities to nutrient manipulations in seawater mesocosms. Appl. Environ. Microbiol. 31, $109-121$.

Paul, J.H., Rose, J.B., Jiang, S.C., Kellogg, C.A., Dickinson, L., 1993. Distribution of viral abundance in the reef environment of Key Largo, Florida. Appl. Environ. Microbiol. 59, 718-724.

Porter, J., Deere, D., Pickup, R., Edwards, C., 1996. Fluorescent probes and flow cytometry: new insights into environmental bacteriology. Cytometry 23, 91-96.

Proctor, L.M., Fuhrman, J.A., 1990. Viral mortality of marine bacteria and cyanobacteria. Nature 343, 60-62.

Rose, J.M., Caron, D.A., Sieracki, M.E., Poulton, N., 2004. Counting heterotrophic nanoplanktonic protists in cultures and aquatic communities by flow cytometry. Aquat. Microb. Ecol. 34, 263-277.

Shopov, A., Williams, S.C., Verity, P.G., 2000. Improvements in image analysis and fluorescence microscopy to discriminate and enumerate bacteria and viruses in aquatic samples. Aquat. Microb. Ecol. 22, 103-110.

Sime-Ngando, T., Mignot, J.-P., Amblard, C., Bourdier, G., Desvilettes, C., Quiblier-Lloberas, C., 1996. Characterization of planktonic virus-like particles in a French mountain lake: methodological aspects and preliminary results. Ann. Limnol. $32,1-5$.

Simon, N., Lebot, N., Marie, D., Partensky, F., Vaulot, D., 1995. Fluorescent in situ hybridization with rRNA-targeted oligonucleotide probes to identify small phytoplankton by flow cytometry. Appl. Environ. Microbiol. 61, 2506-2513.

Steward, G.F., Smith, D.C., Azam, F., 1996. Abundance and production of bacteria and viruses in the Berring and Chukchi Seas. Mar. Ecol., Progr. Ser. 131, 287-300. 
Suttle, C.A., 2000. The ecological, evolutionary and geochemical consequences of viral infection of cyanobacteria and eukaryotic algae. In: Hurst, C.J. (Ed.), Viral Ecology. Academic Press, pp. $248-286$.

Vaulot, D., 1989. CytoPC: processing software for flow cytometric data. Signal Noise 2, 8 .

Veldhuis, M.J.W., Kraay, G.W., 2000. Application of flow cytometry in marine phytoplankton research: current applications and future perspectives. Scient. Mar. 64, 121-134.

Vives-Rigo, J., Lebaron, P., Nebe-von Caron, G., 2000. Current and future applications of flow cytometry in aquatic microbiology. FEMS Microbiol. Rev. 24, 429-448.

Wallner, G., Steinmetz, I., Bitter-Suermann, D., Amann, R., 1996. Combination of rRNA-targeted hybridization and immunoprobes for the identification of bacteria by flow cytometry. Syst. Appl. Microbiol. 19, 569-576.

Weinbauer, M.G., 2004. Ecology of prokaryotic viruses. FEMS Microbiol. Rev. 28, 127-181.

Weinbauer, M.G., Suttle, C.A., 1997. Comparison of epifluorescence and transmission electron microscopy for counting viruses in natural marine waters. Aquat. Microb. Ecol. 13, 225-232.
Wen, K., Ortmann, A.C., Suttle, C.A., 2004. Accurate estimation of viral abundance by epifluorescence microscopy. Appl. Environ. Microbiol. 70, 3862-3867.

Wiggins, B., Alexander, M., 1985. Minimum bacterial density for bacteriophage replication: implications for significance of bacteriophages in natural ecosystems. Appl. Environ. Microbiol. 49, 19-23.

Wommack, K.E., Colwell, R.R., 2000. Virioplankton: viruses in aquatic ecosystems. Microbiol. Rev. 64, 69-110.

Xenopoulos, M.A., Bird, D.F., 1997. Virus à la sauce Yo-Pro: microwave-enhanced staining for counting viruses by epifluorescence microscopy. Limnol. Oceanogr. 42, 1648-1650.

Yentsch, C.M., Horan, P.K., Muirhead, K., Dortch, Q., Haugen, E.M., Legendre, L., Murphy, L.S., Phinney, D., Pomponi, S.A., Spinrad, R.W., Wood, A.M., Yentsch, C.S., Zahurenec, B.J., 1983. Flow cytometry and sorting: a powerful technique with potential applications in aquatic sciences. Limnol. Oceanogr. 28, $1275-1280$. 